\title{
Estudo de genes de resposta imune em pacientes com Hemofilia
}

\section{Study of immune response genes in patients with Hemophilia}

Morgana Ferreira de Barros

Orientador: Jeane Eliete Laguila Visentainer

\section{Resumo}

A hemofilia é uma doença causada pela deficiência dos fatores de coagulação do sangue. A maioria $(80 \%)$ dos casos ocorre por deficiência do fator VIII - hemofilia A ou clássica e $20 \%$ pela deficiência do fator IX - hemofilia B. O tratamento é baseado na reposição de fatores de coagulação. No entanto, além da infecção com vírus da hepatite e HIV, existe um evento adverso mais sério encontrado no tratamento da hemofilia, a formação dos inibidores do fator VIII e IX. Inibidores são aloanticorpos que se ligam no epítopo do Fator VIII, os quais são reconhecidos pelo sistema imune como peptídeos estranhos. Alguns estudos sugeriram que fatores genéticos e ambientais influenciam no desenvolvimento dos inibidores do FVIII. O objetivo deste estudo foi realizar uma revisão da literatura sobre a influência de fatores genéticos e ambientais que possam estar envolvidos no risco do desenvolvimento de inibidores, tendo como foco principal, identificar os genes de resposta imune (HLA de classe I e II) que possam influenciar na formação do inibidor em pacientes com Hemofilia A do Sul do Brasil. Foram realizadas as genotipagens dos alelos de Classe I e II de amostras de sangue de pacientes com hemofilia A cadastrados no estado do Paraná. Os resultados confirmam que o sistema HLA está envolvido na produção do inibidor e poderia ser usado como uma ferramenta para reconhecer grupos de alto risco para o desenvolvimento de inibidores. Após a comparação dos grupos com e sem inibidores, HLA-C*16 $(\mathrm{OR}=7,73$; $\mathrm{P}=0,0092)$ e HLA-DRB1*14 $(\mathrm{OR}=4,52 ; \mathrm{P}=0,0174)$ estavam positivamente associados coma formação dos inibidores. Este estudo pode contribuir ao melhor entendimento dos mecanismos envolvidos na produção de inibidores por alguns indivíduos e não por outros.

Descritores: Fator VIII; Hemofilia A; Antígenos HLA

\section{Abstract}

Hemophilia is a disease caused by a deficiency in blood coagulation factors. The majority $(80 \%)$ of cases occur due to factor VIII deficiency - hemophilia A (classic hemophilia) with factor IX deficiency - hemophilia B occurring in $20 \%$ of cases. Treatment is based on the replacement of coagulation factors. However, as well as infection by hepatitis and HIV, there is a more serious adverse event linked to the treatment of hemophilia, the formation of Factor VIII inhibitor (and less frequently Factor IX inhibitor). This inhibitor is an alloantibody that binds to Factor VIII epitopes and is recognized by the immune system as a foreign peptide. Some studies have suggested that genetic and environmental factors influence the development of Factor VIII inhibitors. The objective of this study was to review the influence of genetic and environmental factors that may be involved in the risk of developing inhibitors with the main focus being to identify immune response genes (HLA class I and II), which may influence the formation of inhibitors in hemophilia A patients from southern Brazil. Genotyping of Class I and II alleles was performed with blood samples from hemophilia A patients in Paraná State. The results confirm that the HLA system is involved in the development of inhibitors. This may be used as a tool to recognize high-risk groups. After a comparison of groups with and without inhibitors, HLA-C*16 $(\mathrm{OR}=7.73, \mathrm{P}=0.0092)$ and HLA-DRB $1 * 14(\mathrm{OR}=4.52, \mathrm{P}=0.0174)$ were found to be positively associated with the formation of inhibitors. This study contributes to a better understanding of the mechanisms involved in the production of inhibitors by some individuals and not by others.

Keywords: Factor VIII; Hemophilia A; HLA Antigens

Avaliação: A RBHH publica os resumos e abstracts de teses da área apresentados em entidades que tenham programas de pós-graduação reconhecidos pelo $\mathrm{MEC/Capes} \mathrm{e} \mathrm{considera} \mathrm{a} \mathrm{obtenção} \mathrm{do} \mathrm{título}$ suficiente para sua publicação na forma como se propõe a seção.

Laboratório de Imunogenética (LIG-UEM), Departamento de Ciências Básicas da Saúde (DBS), Universidade Estadual de Maringá - UEM Maringá (PR), Brasil.

Suporte financeiro: Laboratório de Imunogenética (LIG-UEM) - DBS

Recebido: $21 / 11 / 2010$

Aceito: $25 / 11 / 2010$

Correspondência: Jeane Eliete Laguila Visentainer

Av. Colombo, 5790

87020-900 - Maringá (PR), Brasil

Fax: (55 44) 3011-4931; Tel: (55 44) 3011-4864

E-mail: jelvisentainer@uem.br 